\title{
Sublethal Effects of Essential Plant Oils on Biochemical and Ecological Parameters of the Predatory Mite Amblyseius Swirskii
}

Somayyeh Ghasemzadeh ( $\sim$ s.gasemzadeh@yahoo.com )

Institute of Plant Protection https://orcid.org/0000-0002-8112-8377

Gerben J. Messelink

Business unite greenhouse horticulture

Gonzalo A. Avila

The new Zealand institute for plant and food research limited

Yongjun Zhang

Institute of Plant Protection

\section{Research Article}

Keywords: Biological control, bio-pesticide, energy content, detoxifying enzymes, demographic parameter.

Posted Date: October 21st, 2021

DOI: https://doi.org/10.21203/rs.3.rs-980190/v1

License: (1) This work is licensed under a Creative Commons Attribution 4.0 International License. Read Full License 


\section{Abstract}

The predatory mite Amblyseius swirskii is widely used natural enemy of phytophagous pests. Due to negative effects of conventional pesticides on non-target organism, the development of selective natural and ecofriendly pesticides such as essential plant oils are a useful pest control tool to use in synergy with biological control agents. Essential oils of Nepeta crispa, Satureja hortensis and Anethum graveolens showed promising results to control Tetranychus urticae. Hence an experiment was carried out to evaluate the effects of these essential oils on biochemical and demographic parameters of $A$. swirskii. Significant reduction of carbohydrate, lipid and protein contents of oil-treated predatory mites was observed. However oils of $S$. hortensis and $A$. graveolens had no negative impact on lipid reserve. Glutathione-S-transferase activity of $A$. swirskii was influenced by $A$. graveolens. In addition, the enzyme activity of the $\alpha$-esterases was elevated by all treatments. The essential oils showed no effect on $\beta$ esterases activity compared to the control treatment. None of the concentrations of the different tested oils affected the population growth parameters of $A$. swirskii. However, a significant reduction was observed in oviposition time and total fecundity of predatory mites. Our observations show that the tested essential plant oils need some caution when applied as alternatives to synthetic pesticides in combination with $A$. swirskii and may have critical implications for Integrated Pest Management (IPM) programs. However, semi-field and field studies are required to evaluate the effects of these products on T. urticae and A. swirskii for developing IPM strategies.

\section{Introduction}

The two spotted spider mite, Tetranychus urticae Koch (Acari: Tetranychidae), is a major pest of ornamental plants, vegetable crops and fruit trees grown in greenhouses and open fields across the world (Van de Vrie et al. 1972; Jeppson et al. 1975). Although biological control of spider mites is very successful in most cases (Opit er al. 2004; Gigon et al. 2016), application of synthetic pesticides is still the most common form to control arthropod pests in some agricultural production areas (Monteiro et al. 2015). These pesticides have potential to induce pest resistance, increase production cost and could negatively impact the environment, natural enemies, ecological services and human health (Geiger et al. 2010; Attia et al. 2013; Yorulmaz Salman and Ay 2013). Sublethal insecticide exposure can lead to physiological and behavioral changes in the target organism (Hyne and Maher 2003). Population parameters of the target and non-target species (either harmful or beneficial) may be influenced by the lethal or sublethal concentrations of pesticides (Roush 1989; Desneux et al. 2007; Nadimi et al. 2011; Alinejad et al. 2014; Sarbaz et al. 2017; Ghasemzadeh and Qureshi 2018). Due to negative effects of the pesticides on other beneficial mites and insects (Fernandes et al. 2010; Lira et al. 2015; Shahbaz et al. 2019), over the past few years researches number of studies have focused on essential oil's potential for developing natural pesticides which have well shown biocide effects on a variety of arthropods (Birkett et al. 2010; Ali et al. 2016; Camilo et al. 2017; Fatemikia et al. 2017; Mar et al. 2018).

The use of biological control agents in combination with selective natural insecticides, such as essential plant oils that are environmentally sustainable, can be applied as alternatives to conventional insecticides to control pests. These can not only decrease the side effects of synthetic pesticides but also improve the efficiency of natural enemies in prey searching as shown by low toxicity, non-repellence and in particular cases attractiveness to oils (Oliveira et al. 2017; Freitas et al. 2018; Saraiva et al. 2020). However, caution is needed, because models predict pest resurgence when effective natural enemies are present, even when they are less 
sensitive to pesticides than the pest (Janssen and van Rijn 2021). Essential oils of some species of Nepeta, Satureja and Anethum have been described to possess insecticidal and acaricidal properties (Çalmaşur et al. 2006; Amizadeh et al. 2013; Ebadollahi et al. 2015; Salman and Bayram 2017).

Insects and mites protect themselves against pesticides through detoxifying enzymes which are probably important in resistance development (Yorulmaz Salman and Ay 2014). General esterases and Glutathione-Stransferases (GSTs) are important detoxifying enzymes in the metabolism of synthetic and non-synthetic insecticides (Motoyama 1980; Mouches et al. 1986; Lamoureux and Rusness 1987; Pizzorno 2014). Activities of GST, carboxylesterase, and other metabolic enzymes can be affected by plant protection products (Ross et al. 2010; Mathieu et al. 2015). Although botanical pesticides show potential to be used in conjunction with biological control agents, supplementary studies are required to evaluate the potential direct and indirect effects of the pesticides on natural enemies before it can be recommended for IPM programs (Tedeschi et al. 2001; Momen and Amer 2003; Tavares et al. 2010; Zanuncio et al. 2016; Poderoso et al. 2016; De Araújo et al. 2020). The main goal of this study was to assess whether there are any lethal or sublethal effects of noncommercial essential plant oils of Nepeta crispa Willd (Lamiales: Lamiaceae), Satureja hortensis L. (Lamiales: Lamiaceae) and Anethum graveolens L. (Apiales: Apiaceae) on the predatory mite Amblyseius swirskii AthiasHenriot (Acari: Phytoseiidae). This predatory mite is a widely used natural enemy for biological control of small soft-bodied pest species including mites, thrips and whiteflies (Messelink et al. 2008; Messelink et al. 210; Doğramaci et al.2013; Calvo et al. 2015; Ghasemzadeh et al. 2017). The effects of plant oils were evaluated by assessing the effects of application on the energy contents, the responses of two detoxifying enzymes and the life table parameters of $A$. swirskii.

\section{Material And Methods}

\section{Mite colonies}

The colony of T. urticae started with individuals collected from apple orchards in Urmia (West Azerbaijan province, Iran). Mites were then maintained on potted bean plants (Phaseoulus vulgaris $\mathrm{L}$. var. Talash) (Fabales: Fabaceae) under conditions of $27 \pm 2^{\circ} \mathrm{C}, 60 \pm 5 \%$ relative humidity, and $16 \mathrm{~h}$ light: $8 \mathrm{~h}$ dark photoperiod. Amblyseius swirskii was obtained from Koppert Biological Systems (Berkel en Rodenrijs, The Netherlands) and was reared on $T$. urticae on leaf discs of the bean plants. The leaves were placed upside down on a wet sponge with a layer of cotton on the top in plastic trays with water $(23 \times 13 \mathrm{~cm})$ and held in an environmental chamber at $25 \pm 1^{\circ} \mathrm{C}, 70 \pm 5 \%$ relative humidity, and a photoperiod of $16 \mathrm{~h}$ light: $8 \mathrm{~h}$ dark. All experiments were conducted under these laboratory conditions.

\section{Plant oils and chemical analysis}

Aerial parts of Nepeta crispa Willd, Satureja hortensis L. (Lamiales: Lamiaceae) and Anethum graveolens L. (Apiales: Apiaceae) in flowering stages were harvested from the mountain areas of West-Azerbaijan province (Northwestern Iran) in the middle of August and used for oil extraction.

For a chemical analysis of the plants, aerial parts of plant were dried at room temperature and chopped into small pieces. The samples $(100 \mathrm{~g})$ were hydro-distillated using a Clevenger-type apparatus for $4 \mathrm{~h}$. The obtained essential oils were stored in sealed vials at $-20{ }^{\circ} \mathrm{C}$ for subsequent experiments. 
For GC/MS analysis an Agilent 7890A gas chromatograph coupled to a 5975C mass spectrometer (SpectraLab Scientific Inc., Canada) using a HP-5 MS capillary column (5\% Phenyl Methylpolysiloxane, $30 \mathrm{~m}$ length, $0.25 \mathrm{~mm}$ i.d., $0.25 \mu \mathrm{m}$ film thickness) was used. The oven temperature was programmed as follows: 3 min at $80^{\circ} \mathrm{C}$, subsequently $8^{\circ} \mathrm{C} \min ^{-1}$ to $180^{\circ} \mathrm{C}$, held for $10 \mathrm{~min}$ at $180^{\circ} \mathrm{C}$. Helium was used as carrier gas at a flow rate of $1 \mathrm{~mL} \mathrm{~min} \mathrm{~m}^{-1}$ and Electronimpact (EI) was $70 \mathrm{eV}$. The injector was set in a split mode (split ratio of 1:500) and mass range acquisition was from 40 to $500 \mathrm{~m} / \mathrm{z}$. Essential oil constituents were identified by using the calculated linear retention indices (Wiley 2007; NIST 2005) and mass spectra with those reported in the NIST 05 and Wily 07.

\section{Oil effects on spider mites}

To assess contact toxicity of the essential oils on T. urticae adults, a leaf disc painting method was used in accordance with the procedure described by Miresmailli et al. (2006) with slight modifications. The obtained essential oils of $N$. crispa, S. hortensis and $A$. graveolens were applied at concentration ranges of 19-171 $\mu$ l litre $^{-1}, 33-297 \mu$ liter $^{-1}$ and $23-185 \mu$ litre $^{-1}$ of essential oils in carrier solvent $(70 \%$ methanol $+30 \%$ water), respectively. A $20 \mu$ laliquot of each concentration was painted on the underside of the bean leaf discs ( $\varnothing 2.5$ $\mathrm{cm}$ ) with a micropipette. After drying under laboratory condition for $10 \mathrm{~min}$, each disc was placed in the bottom of a petri dish on top of a $10 \mathrm{~cm}$ diameter disc of filter paper moistened with distilled water. Untreated mites were held on leaf discs painted with the carrier solvent alone. A total of 20 adults of T. urticae were added per bean leaf disc. Each concentration assessed was replicated five times. Mortality was recorded after $24 \mathrm{~h}$ of exposure and the $\mathrm{LC}_{50}$ value of pesticides and essential oils were estimated. Mites were considered dead if they did not move when prodded with a soft paint brush. The highest concentrations of chemicals calculated for $T$. urticae mortality were applied for further experiments with $A$. swirskii.

\section{Oil sideeffects on the biochemical composition of $A$. swirskii}

To test the side-effects of the collected oils on the biochemical composition of $A$. swirskii, we exposed twentyfour h old nongravid females of $A$. swirskii to the highest concentrations of $N$. crispa, S. hortensis and $A$. graveolens. The bean leaf discs were painted with each essential oil and carrier solvent for control and allowed to dry for $10 \mathrm{~min}$. The surviving predatory mites were collected after $24 \mathrm{~h}$ exposure and subsequently used for energy content and enzymes activity determination.

To determine the amount of total carbohydrates, lipid and protein, standard biochemical techniques were used. Protein was measured with the Bradford reagent, lipids with vanillin in phosphoric acid, and carbohydrates with the anthrone reagent.

Total carbohydrates and lipid contents were calculated using the method of Yuval et al. (1998) with slight modifications. Sixty treated adult female individuals were homogenized using a plastic pestle in $62.5 \mu \mathrm{l}$ of $2 \%$ sodium sulphate $\left(\mathrm{Na}_{2} \mathrm{SO}_{4}\right)$. Thereafter, $469 \mu$ of chloroform: ethanol (1:2) was added to the homogenate and samples were centrifuged for $10 \mathrm{~min}$ at $8000 \times g$ at $4^{\circ} \mathrm{C}$.

To determine carbohydrates content, $150 \mu$ of the supernatant were mixed with $100 \mu$ distilled water and then dissolved in $500 \mu \mathrm{l}$ of anthrone reagent (500 mg anthrone dissolved in $500 \mathrm{ml}$ concentrated sulphuric acid $\left(\mathrm{H}_{2} \mathrm{SO}_{4}\right)$ ) for $10 \mathrm{~min}$ at $90^{\circ} \mathrm{C}$. Samples of $200 \mu \mathrm{l}$ were put into wells on ELISA plates (Awareness Technology 
INC, USA) and the rate of absorbance was read at $630 \mathrm{~nm}$. Total carbohydrate value was calculated by standard curve using maltose (Sigma) as standard. This experiment was repeated 3 times for each treatment.

To measure lipids content, $125 \mu \mathrm{l}$ of the supernatant was injected in a micro tube and dried at $40^{\circ} \mathrm{C}$. Then, 125 $\mu \mathrm{l}$ of $\mathrm{H}_{2} \mathrm{SO}_{4}\left(98 \%\right.$ Merck) were added to the sample and placed in a hot bath for $10 \mathrm{~min}$ at $90^{\circ} \mathrm{C}$. Samples of 30 $\mu \mathrm{l}$ were mixed with $270 \mu \mathrm{l}$ of vanillin solution $(600 \mathrm{mg}$ of vanillin in $100 \mathrm{ml}$ distilled water and $400 \mathrm{ml} 85 \%$ $\mathrm{H}_{3} \mathrm{PO}_{4}$ ) and put into wells on ELISA plates (Awareness Technology INC, USA). The plate was shaken for 30 min in shaking incubator at room temperature and subsequently, the absorbance rate was recorded at $545 \mathrm{~nm}$. The amount of total lipid was calculated using cholesterol as standard. This experiment was repeated 3 times for each treatment.

Total protein content was specified based on the Bradford method (1976) using bovine serum albumin as standard. Thirty treated adult female individuals were homogenized with $100 \mu \mathrm{l}$ of phosphate buffer $(\mathrm{pH} 7.0)$ and centrifuged for $10 \mathrm{~m}$ at $10000 \times g$ at $4^{\circ} \mathrm{C}$. The supernatant of $10 \mu \mathrm{l}$ was mixed in $500 \mu$ l Bradford's reagent and the absorbance rate was read at $630 \mathrm{~nm}$ in an ELISA reader (Awareness Technology INC, USA). This experiment was repeated 3 times for each treatment.

The activity of general esterase and GST were determined using the methods of Van Asperen (1962) and Habig et al. (1974), respectively. To assay general esterase, 60 adult treated $A$. swirskii females were homogenized with a plastic pestle in $80 \mu$ l of phosphate buffer $(0.2 \mathrm{M}, \mathrm{pH} 7.0)$ prepared with $0.2 \%$ Triton $\mathrm{X}-100$ (Sigma). $\alpha$-naphthyl acetate ( $\alpha$-NA) and $\beta$-naphthyl acetate $(\beta-N A)$ (Fluka) were used as substrates. The homogenized solution was centrifuged at $12,000 \times g$ for 10 minutes at $4^{\circ} \mathrm{C}$. The supernatant of $13 \mu \mathrm{l}$ and 112 $\mu \mathrm{l}$ of phosphate buffer was added to a 96-well microplate. The reaction was initiated by addition of $50 \mu \mathrm{l}$ of substrate solution ( $0.65 \mathrm{mM}$ in buffer) per well. After $15 \mathrm{~min}$ incubation at room temperature, $50 \mu \mathrm{l}$ fast blue RR salt (Fluka) was added and the microplate left in dark conditions for $30 \mathrm{~min}$. The esterase enzyme activity was calculated at $450 \mathrm{~nm}$ and $540 \mathrm{~nm}$ for $\alpha$-NA and $\beta$-NA, respectively, with 16 intervals of 30 seconds using microplate reader (Awareness Stat Fax_ 3200).

To determine GST activity, 1-chloro-2,4-dinitrobenzene (CDNB, Merck, Germany) and reduced GSH were used as the substrates. Sixty treated adult females of $A$. swirskii were homogenized in $80 \mu$ l of phosphate buffer $(0.2$ $\mathrm{M}, \mathrm{pH}$ 7.0) in Eppendorf tubes using a plastic pestle and followed by centrifugation at $12,000 \times g$ for $10 \mathrm{~min}$ at $4^{\circ} \mathrm{C}$. The supernatant of $15 \mu \mathrm{l}$ was mixed with $110 \mu \mathrm{l} 0.2 \mathrm{M}$ (pH 7.0) of phosphate buffer, $80 \mu \mathrm{l}$ of CDNB and $100 \mu \mathrm{l}$ of GSH in buffer. The absorbance rate was continuously measured at $340 \mathrm{~nm}$ with 16 intervals of 30 seconds.

\section{Sideeffects of oils on the biological parameters of $A$. swirskii}

All experiments were conducted on fresh-excised bean leaf disks $(2.5 \times 2.5 \mathrm{~cm})$ that were placed upside down in $30-\mathrm{ml}$ transparent plastic cups containing water agar mixture (10\%) under conditions of $25 \pm 1^{\circ} \mathrm{C}, 70 \pm 5 \%$ relative humidity, and a photoperiod of $16 \mathrm{~h}$ light: $8 \mathrm{~h}$ dark. Lids were provided with a vent covered with insect gauze. To study the effect of essential oils of $N$. crispa, S. hortensis and A. graveolens on A. swirskii, bean leaf discs were painted with each essential oil and carrier solvent, or with the carrier solvent alone as a control treatment, and allowed to dry for $10 \mathrm{~min}$ (Miresmailli et al. 2006). A cohort of seventy five 24-h old females of A. swirskii from untreated bean plants were placed individually on leaf discs of each treatment and control. 
After $24 \mathrm{~h}$, forty surviving females from each treatment and control were moved separately to untreated bean leaf discs and individually placed on discs. Following $24 \mathrm{~h}$, the eggs laid by individual females in each experimental arena were stored as per above conditions at one egg per disc per female. The cohort of 0-24 $\mathrm{h}$ old eggs from each female was kept through eclosion of nymphs and followed through development to adult. During their development, five adults of spider mites T. urticae were provided daily as prey. Experimental arenas were checked daily to record survival and developmental time of the different life stages. The leaves were replaced every three days (in case of necessary). Each newly emerged female from four treatments were coupled with an untreated male for mating as per above conditions. Survival and fecundity was recorded until the death of the last individual.

\section{Statistical analysis}

Mortality curves of spider mites were estimated by probit analysis (SPSS 2012). A generalized linear model (GLM) with binomial distribution with logit function was used to investigate differences in mortality rates of $T$. urticae between different oil concentrations for each of the three plant species tested. Results from trials conducted with $A$. swirskii to assess the side effects of the different oils on its biochemical composition were analyzed with one-way analysis of variance (ANOVA) followed by Tukey's test to compare differences among various treatments.

Raw data on the survivorship, longevity, and daily fecundity of individual females were analyzed using the agestage specific (Chi and Liu 1985; Chi 1988) and TWOSEX life table using both genders in computer program MSChart (Chi 2017). Means and standard errors of the population parameters were estimated by the Bootstrapping procedure with 100,000 replications (Efron and Tibshirani 1993; Reddy and Chi 2015).

Bootstrapping uses random resampling, otherwise a small number of replications will generate variable means and large standard errors. Differences between means were compared using the paired bootstrap test at the $5 \%$ level of significance (Reddy and Chi 2015).

Following Chi (Chi and Liu 1985; Chi 1988; Chi and Su 2006; Chi 2017), the age-stage specific survival rate $\left(s_{x j}\right)$, where $x$ is age and $j$ is the stage; age-stage life expectancy $\left(e_{x j}\right)$; the age-specific survival rate $\left(I_{x}\right)$; the agespecific fecundity $\left(m_{x}\right)$; the net reproductive rate $\left(R_{0}\right)$; the intrinsic rate of increase $(r)$; the finite rate of increase $(\lambda)$; the mean generation time (T) and the doubling time (DT) were calculated:

$$
\begin{array}{ll}
l_{x}=\sum_{j=1}^{\beta} s_{x j} & m_{x}=\frac{\sum_{j=1}^{\beta} s_{x j} f_{x j}}{\sum_{j=1}^{\beta} s_{x j}} \\
R_{0}=\sum_{x=0}^{\infty} l_{x} m_{x} & \sum_{x=0}^{\infty} e^{-r(x+1)} l_{x} m_{x}=1
\end{array}
$$

Where $a$ is the number of age groups and $\beta$ is the number of stages. 

$\lambda=e^{r}$
$T=\frac{\ln R_{0}}{r}$
$D T=\frac{\ln 2}{r}$

\section{Results}

\section{Chemical composition of the oils}

Chemical components analysis of the essential oils revealed that the predominant chemical compound found on $N$. crispa oil was 1,8-Cineole (57.68\%). Predominant essential oil compounds found on S. hortensis were carvacrol (34.75\%), gamma-terpinene (34.28\%) and para-cymene (16.96\%). L-phellandrene (34.18\%), Carvone (23.68\%) and limonene (21.46\%) were the main compounds identified in A. graveolens oil (Table 1).

Table 1 Chemical composition of the essential oils of N. crispa, S. hortensis and A. graveolens 


\begin{tabular}{|c|c|c|c|c|c|c|c|}
\hline Plant & Component & aRRI & $\begin{array}{l}\text { Composition } \\
\%\end{array}$ & Plant & Component & ${ }^{a}$ RRI & $\begin{array}{l}\text { Composition } \\
\%\end{array}$ \\
\hline \multirow[t]{12}{*}{ N. crispa } & & & & & Para-cymene & 1028 & 16.98 \\
\hline & $\begin{array}{l}\text { Alpha- } \\
\text { pinene }\end{array}$ & 939 & 2.50 & & Limonene & 1034 & 0.74 \\
\hline & Sabinene & 974 & 2.08 & & 1,8-cineole & 1038 & 0.28 \\
\hline & Beta-pinene & 982 & 6.54 & & $\begin{array}{l}\text { Gamma- } \\
\text { terpinene }\end{array}$ & 1062 & 34.28 \\
\hline & $\begin{array}{l}\text { Beta- } \\
\text { myrcene }\end{array}$ & 993 & 0.42 & & Menthol & 1176 & 0.50 \\
\hline & $\begin{array}{l}\text { Para- } \\
\text { cymene }\end{array}$ & 1028 & 1.43 & & Thymol & 1298 & 0.27 \\
\hline & Limonene & 1034 & 1.37 & & Carvacrol & 1308 & 34.75 \\
\hline & 1,8-cineole & 1038 & 57.68 & & $\begin{array}{l}\text { Trans- } \\
\text { caryophyllene }\end{array}$ & 1427 & 0.29 \\
\hline & $\begin{array}{l}\text { Gamma- } \\
\text { terpinene }\end{array}$ & 1062 & 1.19 & & $\begin{array}{l}\text { Caryophyllene } \\
\text { oxide }\end{array}$ & 1592 & 0.23 \\
\hline & Linalool & 1098 & 1.26 & $\begin{array}{l}\text { A. } \\
\text { graveolens }\end{array}$ & & & \\
\hline & $\begin{array}{l}\text { Terpinene-4- } \\
\text { ol }\end{array}$ & 1183 & 1.74 & & Beta-myrcene & 993 & 0.74 \\
\hline & $\begin{array}{l}\text { Alpha } \\
\text { terpineol }\end{array}$ & 1195 & 4.45 & & $\begin{array}{l}\mathrm{L}- \\
\text { phellandrene }\end{array}$ & 1006 & 34.18 \\
\hline \multirow{6}{*}{$\begin{array}{l}\text { S. } \\
\text { hortensis }\end{array}$} & & & & & Para-cymene & 1028 & 5.53 \\
\hline & $\begin{array}{l}\text { Alpha- } \\
\text { pinene }\end{array}$ & 939 & 1.96 & & Limonene & 1034 & 21.46 \\
\hline & Beta-pinene & 982 & 0.87 & & $\begin{array}{l}\text { Gamma- } \\
\text { terpinene }\end{array}$ & 1062 & 0.77 \\
\hline & $\begin{array}{l}\text { Beta- } \\
\text { myrcene }\end{array}$ & 993 & 1.88 & & $\begin{array}{l}\text { Alpha- } \\
\text { terpineol }\end{array}$ & 1190 & 5.57 \\
\hline & $\begin{array}{l}\text { Alpha- } \\
\text { phellandrene }\end{array}$ & 1007 & 0.33 & & Carvone & 1251 & 23.68 \\
\hline & $\begin{array}{l}\text { Alpha- } \\
\text { terpinene }\end{array}$ & 1019 & 2.77 & & Carvacrol & 1308 & 0.79 \\
\hline
\end{tabular}

${ }^{a}$ RRI: Relative retention index

Oil effects on $T$. urticae 
Mortality rates of $T$. urticae adults were significantly different among oil concentrations of $N$. crispa (Wald $\chi^{2}=$ 115.9; $d f=4 ; P<0.001)$, S. hortensis (Wald $\chi^{2}=102.5 ; d f=4 ; P<0.001$ ) and $A$. graveolens (Wald $\chi^{2}=105.2 ; d f$ $=4 ; P<0.001)$. The highest concentrations resulted in an average mortality of about $90 \%$ after $24 \mathrm{~h}$ exposure (Fig. 1). No mortality was recorded in control group.

Probit analysis data of acute toxicity of $T$. urticae adults in response to the three oils revealed the median lethal concentration $\left(\mathrm{LC}_{50}\right)$ values, which were the highest for $S$. hortensis and the lowest for $N$. crispa (Table 2).

Table 2 Median lethal concentration ( $\left.\mathrm{LC}_{50}\right)$ estimated using probit analysis for adult female T. urticae exposed to $N$. crispa, S. hortensis and A. graveolens for $24 \mathrm{~h}$

\begin{tabular}{|llllll|}
\hline Pesticide & LC $(50)\left(\mu\right.$ liter $\left.^{-1}\right)$ & $95 \%$ Confidence limits & Slope \pm SE & $\chi^{2}$ & $d f$ \\
\hline N. crispa & 32.04 & $29.01-35.47$ & $2.86 \pm 0.24$ & 0.93 & 3 \\
\hline S. hortensis & 136.00 & $126.07-146.24$ & $3.85 \pm 0.35$ & 1.24 & 3 \\
A. graveolens & 73.07 & $64.66-82.48$ & $2.32 \pm 0.20$ & 3.05 & 3 \\
\hline
\end{tabular}

\section{Sideeffects on biochemical parameters of $A$. swirskii}

Calculation of total available energy as the sum of the energy contents, shows that treatments with the oils of N. crispa, $S$. hortensis and $A$. graveolens significantly reduced the total carbohydrates content $\left(F_{3,8}=6.16 ; P<\right.$ 0.018), lipid content $\left(\mathrm{F}_{3,8}=6.30 ; P<0.017\right)$ and protein content $\left(\mathrm{F}_{3,8}=9.75 ; P<0.005\right)$ in the females of $A$. swirskii compared to the control treatment. However treatments of $S$. hortensis and $A$. graveolens did not reduce lipid content in comparison to the control treatment (Fig. 2).

Exposure of $A$. swirskii adults to the three essential oils had a significant effect on the detoxification enzyme activity of GST enzyme $\left(\mathrm{F}_{3,8}=5.15 ; P<0.028\right)$ and the $\alpha$-esterase enzyme $\left(\mathrm{F}_{3,8}=47.56 ; P<0.0001\right)$, but not on the $\beta$-esterase enzyme $\left(\mathrm{F}_{3,8}=1.16 ; P<0.38\right)$ (Fig. 3). All oil treatments resulted in a higher $\alpha$-esterase enzyme activity compared to the control, with the highest levels for $S$. hortensia, whereas the GST enzyme activity was only higher for the $A$. graveolis oil treatment compared to the control treatment (Fig. 3).

\section{Sideeffects on demographic parameters of $A$. swirskii}

The application of $N$. crispa, S. hortensis and A. graveolens oils considerably affected developmental time, longevity and total life span of the progeny of $A$. swirskii females (Table 3 ). Duration of egg and larva stages of female and male from females exposed to the three treatments were not significantly different from the untreated control, but with an exception of $N$. crispa effects on the larva stage of females. There was no significant difference between treatments and control for protonymph and deutonymph duration of female and male (Table 3). However, developmental time of females was significantly prolonged in all treatments compared to the control treatment, but this was not the case for males. Female longevity compared to control was most significantly reduced by oil application of $N$. crispa and $A$. graveolens followed by $S$. hortensis. A similar effect was observed for males. Each of three tested treatments significantly reduced the total life span 
of both genders compared to the control treatment, with most impact from N. crispa and A. graveolens (Table 3).

Table 3 Mean $( \pm S E)$ developmental time, longevity and total life span (days) of offspring from females of $A$. swirskii from control or treatments of N. crispa, S. hortensis and A. graveolens

\begin{tabular}{|c|c|c|c|c|c|}
\hline \multicolumn{6}{|l|}{ Treatments } \\
\hline Sex/stage & N. crispa & S. hortensis & A. graveolens & Control & F value $^{*}$ \\
\hline \multicolumn{6}{|l|}{ Female } \\
\hline Egg duration & $1.76 \pm 0.12 a$ & $1.73 \pm 0.10 a$ & $1.70 \pm 0.11 a$ & $1.48 \pm 0.11 a$ & 33.36 \\
\hline Larva duration & $1.33 \pm 0.11 a$ & $1.27 \pm 0.10 \mathrm{ab}$ & $1.25 \pm 0.10 \mathrm{ab}$ & $1.09 \pm 0.06 b$ & 30.54 \\
\hline Protonymph & $1.81 \pm 0.11 a$ & $1.82 \pm 0.13 a$ & $1.71 \pm 0.13 a$ & $1.74 \pm 0.16 a$ & 3.99 \\
\hline Deutonymph & $2.00 \pm 0.17 a$ & $1.91 \pm 0.17 a$ & $1.85 \pm 0.17 a$ & $1.87 \pm 0.17 a$ & 3.32 \\
\hline Developmental time & $6.90 \pm 0.23 a$ & $6.73 \pm 0.22 b$ & $6.51 \pm 0.179 a$ & $6.17 \pm 0.29 c$ & 3122.13 \\
\hline Longevity & $18.10 \pm 0.22 c$ & $19.32 \pm 0.19 b$ & $18.20 \pm 0.17 c$ & $23.09 \pm 0.22 a$ & 3122.13 \\
\hline Total life span & $25.00 \pm 0.35 c$ & $26.05 \pm 0.28 b$ & $24.71 \pm 0.26 c$ & $29.26 \pm 0.32 a$ & 1026.86 \\
\hline \multicolumn{6}{|l|}{ Male } \\
\hline Egg duration & $1.82 \pm 0.15 a$ & $1.67 \pm 0.14 a$ & $1.61 \pm 0.14 a$ & $1.53 \pm 0.12 a$ & 13.55 \\
\hline Larva duration & $1.41 \pm 0.16 a$ & $1.39 \pm 0.14 a$ & $1.28 \pm 0.11 a$ & $1.24 \pm 0.11 a$ & 7.82 \\
\hline Protonymph & $1.88 \pm 0.15 a$ & $1.83 \pm 0.12 a$ & $1.72 \pm 0.14 a$ & $1.76 \pm 0.11 a$ & 5.53 \\
\hline Deutonymph & $1.65 \pm 0.12 a$ & $1.61 \pm 0.12 a$ & $1.56 \pm 0.12 a$ & $1.53 \pm 0.15 a$ & 3.04 \\
\hline Developmental time & $6.76 \pm 0.34 a$ & $6.50 \pm 0.34 a$ & $6.17 \pm 0.34 a$ & $6.06 \pm 0.20 a$ & 19.21 \\
\hline Longevity & $17.04 \pm 0.23 c$ & $18.33 \pm 0.24 b$ & $17.50 \pm 0.32 c$ & $22.35 \pm 0.44 a$ & 1048.89 \\
\hline Total life span & $23.71 \pm 0.43 c$ & $24.83 \pm 0.26 b$ & $23.67 \pm 0.33 c$ & $28.41 \pm 0.49 a$ & 598.96 \\
\hline
\end{tabular}

Means followed by different letters in the same row are significantly different by using paired bootstrap test based on $\mathrm{Cl}$ of difference $(P<0.05)$

${ }^{\star} \mathrm{F}(\mathrm{df}, \mathrm{n})$ : female $(3,82)$, male $(3,66)$

\section{Reproduction and population growth parameters of $\boldsymbol{A}$. swirskii}

N. crispa and $A$. graveolens treatments resulted in a significantly prolonged pre-oviposition time compared to the control treatment (Table 4). Oviposition time was significantly reduced compared to the control in treatments with an exception of $S$. hortensis. Total fecundity of $A$. swirskii was negatively affected by all oil treatments. A similar effect was observed for the post-oviposition time (Table 4). 
Table 4 Mean $( \pm S E)$ reproductive period and total fecundity of offspring from females of $A$. swirskii from control or treatments of N. crispa, S. hortensis and A. graveolens

\begin{tabular}{|llllll|}
\hline Treatments & N. crispa & S. hortensis & A. graveolens & Control & Fvalue $^{*}$ \\
\hline Pre-oviposition (day) & $3.48 \pm 0.11 \mathrm{ab}$ & $3.27 \pm 0.13 \mathrm{bc}$ & $3.65 \pm 0.11 \mathrm{a}$ & $3.17 \pm 0.08 \mathrm{c}$ & 80.87 \\
\hline Oviposition (day) & $11.38 \pm 0.26 \mathrm{~b}$ & $12.41 \pm 0.21 \mathrm{a}$ & $10.90 \pm 0.26 \mathrm{~b}$ & $12.91 \pm 0.18 \mathrm{a}$ & 357.17 \\
\hline Post-oviposition (day) & $4.92 \pm 0.10 \mathrm{~b}$ & $5.15 \pm 0.13 \mathrm{~b}$ & $5.35 \pm 0.13 \mathrm{~b}$ & $6.20 \pm 0.11 \mathrm{a}$ & 278.00 \\
\hline Total fecundity (offspring) & $11.57 \pm 0.24 \mathrm{c}$ & $12.59 \pm 0.22 \mathrm{~b}$ & $11.40 \pm 0.27 \mathrm{c}$ & $13.57 \pm 0.26 \mathrm{a}$ & 359.66 \\
\hline
\end{tabular}

Means followed by different letters in the same row are significantly different by using paired bootstrap test based on $\mathrm{Cl}$ of difference $(P<0.05)$

${ }^{*} \mathrm{~F}(\mathrm{df}, \mathrm{n}):(3,82)$

Age-specific survival rate $\left(I_{x}\right)$ and age-specific fecundity of the total population $\left(m_{x}\right)$ exposed to essential oils were compared with populations in the control treatment (Fig. 4). Regardless the developmental stage, $I_{x}$ represents the probability that an egg will survive to age $x$, and the curve of the age-specific survival rate is a simplified form of the curves of age-stage survival rate. Total life span averaged 29.26 days for the untreated females and 25.00 days, 26.05 days and 24.71 days for the females treated with highest concentrations of $N$. crispa, $S$. hortensis and $A$. graveolens, respectively. Comparison of the survival $\left(I_{x}\right)$ of untreated mites and those treated with essential oils of $N$. crispa and $A$. graveolens revealed 4.9 and $5.30 \%$ mortality in the immature stages, with 95.1 and $94.7 \%$ chance of reaching adulthood, respectively. However the mites treated with S. hortensis showed no mortality in immature stages, with $100 \%$ chances of reaching adulthood.

Maximum $m x$ of 0.78 eggs/female/day was observed on day 11 for untreated mites. For mites treated with $N$. crispa, S. hortensis and A. graveolens, $m x$ was approximately $0.61,0.60$ and 0.63 eggs/female/day, respectively, which occurred on days 15, 13 and 16 of life span, respectively. Based on the age-stage specific survival rate of both untreated and treated individuals of $A$. swirskii, the probability that an egg will survive to age $\mathrm{x}$ and develop to stage $\mathrm{j}$ was illustrated. Compared to the control, N. crispa and A. graveolens increased the pre-oviposition period. Male adults emerged simultaneously with females.

The age-stage survival rate $\left(s_{x j}\right)$ represents the probability that an egg of $A$. swirskii will survive to age $x$ and stage $j$. There is an overlap in the curves at different developmental periods among the individuals in all treatments. The highest female survival rate was observed in control compared with other treatments and $57.50 \%$ of eggs normally developed to the adult stage (Fig. 5).

There was no significant effect of the highest concentration of essential oils on the population parameters including intrinsic rate of increase $(\eta)$, the finite rate of increase $(\lambda)$, the net reproductive rate $\left(R_{0}\right)$, the gross reproductive rates $(G R R)$ and the mean generation time $(T)$ (Table 5$)$. 
Table 5 Mean $( \pm S E)$ population parameters of the females of Amblyseius swirskii from control or treatments of N. crispa, S. hortensis and A. graveolens

\begin{tabular}{|c|c|c|c|c|c|}
\hline & \multicolumn{5}{|l|}{ Treatments } \\
\hline & N. crispa & S. hortensis & $\begin{array}{l}\text { A. } \\
\text { graveolens }\end{array}$ & Control & $\begin{array}{l}\mathrm{F} \\
\text { value* }\end{array}$ \\
\hline Intrinsic rate of increase, $r\left(\right.$ day $\left.^{-1}\right)$ & $\begin{array}{l}0.11 \pm \\
0.01 \mathrm{a}\end{array}$ & $\begin{array}{l}0.12 \pm \\
0.01 \mathrm{a}\end{array}$ & $\begin{array}{l}0.11 \pm \\
0.01 \mathrm{a}\end{array}$ & $\begin{array}{l}0.13 \pm \\
0.01 \mathrm{a}\end{array}$ & 42.11 \\
\hline Finite rate of increase, $\lambda\left(\right.$ day $\left.^{-1}\right)$ & $\begin{array}{l}1.12 \pm \\
0.01 \mathrm{a}\end{array}$ & $\begin{array}{l}1.13 \pm \\
0.01 \mathrm{a}\end{array}$ & $\begin{array}{l}1.12 \pm \\
0.01 \mathrm{a}\end{array}$ & $\begin{array}{l}1.14 \pm \\
0.01 \mathrm{a}\end{array}$ & 42.56 \\
\hline $\begin{array}{l}\text { Net reproductive rate, } R_{0} \\
\text { (offspring) }\end{array}$ & $\begin{array}{l}6.07 \pm \\
0.92 \mathrm{a}\end{array}$ & $\begin{array}{l}6.92 \pm \\
0.99 a\end{array}$ & $\begin{array}{l}5.70 \pm \\
0.90 \mathrm{a}\end{array}$ & $\begin{array}{l}7.80 \pm \\
1.09 a\end{array}$ & 36.55 \\
\hline $\begin{array}{l}\text { Gross reproductive rate, GRR } \\
\text { (offspring) }\end{array}$ & $6.47 \pm 094 a$ & $\begin{array}{l}6.95 \pm \\
0.99 a\end{array}$ & $\begin{array}{l}6.04 \pm \\
0.93 a\end{array}$ & $\begin{array}{l}7.80 \pm \\
0.09 a\end{array}$ & 23.10 \\
\hline Mean generation time, $\mathrm{T}$ (day) & $\begin{array}{l}15.93 \pm \\
0.23 a\end{array}$ & $\begin{array}{l}15.85 \pm \\
0.23 a\end{array}$ & $\begin{array}{l}15.58 \pm \\
0.25 \mathrm{a}\end{array}$ & $\begin{array}{l}15.23 \pm \\
0.29 \mathrm{a}\end{array}$ & 60.70 \\
\hline
\end{tabular}

Means followed by different letters in the same row are significantly different by using paired bootstrap test based on $\mathrm{Cl}$ of difference $(P<0.05)$

${ }^{*} \mathrm{~F}(\mathrm{df}, \mathrm{n}):(3,156)$

The age-stage-specific life expectancy ( $e_{x j}$ : the period that an individual of age $x$ and stage $j$ is expected to survive) of $A$. swirskii individuals was affected by treatments. According to the exj curve of newborns $\left(e_{01}\right)$, predatory mite was expected to live 20.00, 21.04, 19.66 and 25.26 days in N. crispa, S. hortensis and $A$. graveolens and control, respectively (Fig. 6).

\section{Discussion}

Over past decade, there has been an increased attention to use extracted oils from plants as alternatives for the conventional synthetic pesticides to control pests and prevent negative effects on natural enemies (Momen et al. 2001; Regnault-Roger et al. 2012; Isman and Grieneisen 2014; Pavela 2015; Nicolle et al. 2016; Atanasova and Leather 2018). The essential oils of Nepeta sp. Satureja sp. and Anethum proved highly toxic to T. urticae (Aslan et al. 2004; Çalmaşur et al. 2006; Miresmailli et al. 2006), as also confirmed in this study. Investigation of the compatibility of plant-based acaricides and biocontrol agents is crucial for execution of IPM strategies (De Araújo et al. 2020). Therefore studies are needed to assess side-effects of biopesticides on beneficial organisms.

The present study evaluated the effects of the highest concentration rates of N. crispa, S. hortensis and $A$. graveolens on biochemical and demographic parameters of $A$. swirskii. The results demonstrated significant reduction in carbohydrate, lipid and protein contents of $A$. swirskii after exposure to the essential oils, except that lipid content in $S$. hortensis and A. graveolens treatments was not significantly different from the control treatment. It is likely that the reduction of carbohydrate content may be due to the antifeedant effect and an 
increase in metabolism under toxicant stress (Remia et al. 2008). Lipids are an important source of energy and are reserved in body fat. The reserve of lipids during the feeding period increases but is reduced in non-feeding stage (Chapman 1998). The amount of total lipid levels of oil-treated $A$. swirskii females significantly reduced when compared to the control treatment. This reduction in lipid content of treated insects might have been caused by the effect of insecticide on the adipokinetic hormone that modulates the lipid metabolism (Sak et al. 2006). Proteins play a fundamental role in biochemical reactions and hormonal regulation in all known species (Sugumaran 2010). Decrease in protein content was observed in treated $A$. swirskii female compared to the control treatment. Reduction in protein content is a common phenomenon in insects after a treatment with toxic compounds (Nathan et al. 2008). It is likely that the insect degrades proteins to resultant amino acids in order to let them enter the TCA cycle (tricarboxylic acid cycle) as a keto acid for compensation of lower energy caused by stress (Bizhannia et al. 2005). Protein level reduction might be caused by the destructive effect of IGRs on central nervous system (Baker et al. 2009). Similar biochemical responses were found for insects treated with pesticides. Bashari et al. (2014) showed that hexaflumuron significantly decreased total carbohydrate, lipid and protein content of third instar larvae of Xanthogaleruca luteola Müll (Coleoptera: Chrysomelidae). Also clear decreases of total protein levels were observed in fifth instar larvae of Bombyx mori Linnaeus (Lepidoptera: Bombycidae) after treatments with pyriproxyfen at 10, 75, 150 and 500 ppm concentrations (Etebari et al. 2007). Sak et al. (2006) also verified the striking decrease in glycogen, lipid and protein reserve of Pimpla turionellae L. (Hymenoptera: Ichneumonidae) exposed to cypermethrin.

An alternative way to analyze biochemical responses of organisms to pesticides is measuring the detoxification enzyme activity. The enzyme GST plays an important role in biotransformation and degradation of various pesticides (Yang 1976; Motoyama 1980). The activities of GST increased in treated predatory mite with $A$. graveolens as compared to control but not in $N$. crispa and $S$. hortensis. a-Esterase activity substantially increased in treated $A$. swirskii female compared to control, but levels of the enzyme $\beta$-esterase were not changed in response to oil treatments. Our results agree with Farahani et al. (2020) who found that the activity of GST and esterase ( $\mathrm{a}-\mathrm{Na}$ ) significantly increased in $T$. urticae treated with some essential oils of Lamiaceae family. By contrast, GST, $a$ - and $\beta$-esterase activities were reduced by exposure to high concentrations of Cymbopogon flexuosus essential oil in Aedes aegypti L. (Diptera: Culicidae) (Carreño et al. 2018). Similarly, Liao et al. (2017) and Gao et al. (2019) reported inhibitory effects of essential oils on insect detoxifying enzymes. This suppression of GST activity after exposure to pesticides in target and non-target species, have been extensively studied (Usui et al. 1977; Hayaoka and Dauterman 1982; Hodge et al. 2000; Gholamzadeh-Chitgar et al. 2015). GSTs are involved in detoxification of xenobiotics and protection of organisms from oxidative damage and play an essential role in detoxification of insecticides and thus rendering them less or non-toxic (Hayes and 1995; Rufingier et al. 1999). Esterases are classified as hydrolases, a large and diverse group of enzymes participating in xenobiotic detoxification by surrounding toxic compounds and consequently preventing them from gaining access to the target site (Dauterman 1985; Hayes and 1995). Differences in populations, the mode of action of essential oils, concentrations and time of exposure could explain variability in the results reported in different studies (Liao et al. 2017; Shojaei et al. 2017).

The highest concentrations of $N$. crispa, $S$. hortensis and $A$. graveolens prolonged developmental time of $A$. swirskii female. These effects may eventually result in a reduced population growth of this predator. Similar effects were observed on developmental time duration of T. urticae when exposed to sublethal concentrations 
of Cinnamomum zeylanicum Blume (Laurales: Lauraceae) (Rezaei et al. 2014). Also the longevity and total life span of $A$. swirskii were in all oil treatments reduced. Overall, $S$. hortensis had the strongest negative effect on A. swirskii followed by N. crispa and A. graveolens. Similar effects of aromatic plant oils on female longevity have been reported when T. urticae was exposed to C. zeylanicum (Rezaei et al. 2014), Artemisia annua L. and Rosmarinus officinalis L. essential oils (Esmaeily et al. 2017). Similar observations have been reported in other studies, where plant extracts also negatively affected the life cycle of insects (Gaspari et al. 2007; Poderoso et al. 2016).

Reproductive variables of $A$. swirskii after exposure to oils from $N$. crispa, S. hortensis and A. graveolens were reduced compared to untreated mites. Also here similar effects were found for other insects and mites.

Fecundity reduced when Brevicoryne brassicae (Hemiptera: Aphididae) was treated with sublethal concentration of Thymus daenensis pure essential oil and its nanocapsule (Heidary et al. 2020). Fecundity of Neoseiulus californicus McGregor (Acari: Phytoseiidae) also decreased substantially when exposed to sublethal concentrations of diflovidazin (Havasi et al. 2019). Although a commercial formulation of azadirachtin significantly reduced fecundity of Neoseiulus baraki Athias-Henriot (Acari: Phytoseiidae) (Lima et al. 2015), garlic extract compounds did not have a significant effect on fecundity of $P$. maculiventris (Mamduh et al. 2017).

The full rate treatments of tested essential oils significantly reduced the age-specific survival and fecundity of A. swirskii, however, S. hortensis had negligible impact on the mite survival. Exposure of predatory bug Nesidiocoris tenuis Reuter (Hemiptera: Miridae) to formulations of citrus essential oils produced similar impact on survival of the predator (Campolo et al. 2020). The essential oil of Ferula asafoetida L. (Umbelliferae) led to significant reduction in fecundity and survival rate of parasitoids Trichogramma embryophagum (Hartig) and T. evanescens Westwood (Hymenoptera: Trichogrammatidae) (Poorjavad et al. 2014). Sublethal concentrations of a natural based acaricide with commercial name of Biomite ${ }^{\circledR}$ caused significant reduction in age-specific fecundity and survival curves of $N$. californicus compared with control treatment (Havasi et al. 2020). These discrepancies could be due to the susceptibility of different species, experiment methods, different chemical constituents, formulations and the concentrations (Obeng-Ofori et al. 1997; Zekri et al. 2013).

The assessments on population growth and reproductive rates of treated and untreated females of $A$. swirskii showed that the examined essential oils did not negatively affect $r_{m}, \lambda, R_{0}$ and $G R R$ of the predatory mite at the highest concentrations. In accordance to our results, diflovidazin (Havasi et al. 2019) and Biomite ${ }^{8}$ (Havasi et al. 2020) didn't have significant effect on the $r_{m}$ and $\lambda$ of $N$. californicus. In contrast to our result, plant essential oils significantly reduced the values of $r_{m}$ and $\lambda$ of other arthropods (Esmaeily et al. 2017; Mamduh et al. 2017; Saraiva et al. 2020). Differences in species, populations, experimental method, formulations and concentrations could be responsible for different results between studies. Our findings regarding to $R_{0}$ and GRR of $A$. swirskii in treatments of essential oils were in partial agreement with other reports indicating that the parameters were not significantly different when arthropods are exposed to biopesticides (Mamduh et al. 2017; Havasi et al. 2020). However, in a similar study looking at the sublethal effects of Artemisia annua L. and Rosmarinus officinalis L. essential oils on T. urticae, authors report that the values of $R_{0}$ and GRR demonstrated a declining trend after exposures to sublethal concentrations of essential oils of tested plants (Esmaeily et al. 2017). 
The age-specific survival rate $\left(I_{x}\right)$, age specific fecundity $\left(m_{x}\right)$, age-stage specific survival rate $\left(s_{x j}\right)$ and agestage life expectancy $\left(e_{x j}\right)$ curves were significantly reduced in $A$. swirskii treated with highest concentration of $N$. crispa and $A$. graveolens compared to untreated mites, whereas $S$. hortensis was negligible influential. Similar results were reported on Podisus nigrispinus, where survival rates of this predatory stink bug declined at different concentrations of neem oil (Zanuncio et al. 2016). Reduction in T. urticae life expectancy $\left(e_{x j}\right)$ is an effect of essential oils treatment (Rezaei et al. 2014; Esmaeily et al. 2017). Garlic extract reduced age-stagespecific survival rate $\left(s_{x j}\right)$ of $P$. maculiventris (Mamduh et al. 2017). Sublethal concentrations of Biomite ${ }^{\circledR}$ caused significant reduction in the age-specific fecundity $\left(m_{x}\right)$ and survival $\left(I_{x}\right)$ curves of $N$. californicus (Havasi et al. 2020).

Overall, exposure of $A$. swirskii to the highest residual concentrations of $N$. crispa, S. hortensis and $A$. graveolens had disruptive effects on the energy reserves, survival, longevity and fecundity of the predatory mite. Nevertheless, the essential oils showed no substantial change in population parameters $\left(r_{m}, \lambda\right.$ and $\left.R_{0}\right)$. The intrinsic rate of increase $(r)$ is considered as the best measure for evaluating the total effects of a pesticide (Moscardini et al. 2013) and the use of $r$ has been highlighted as an ecologically bioassay parameter for toxicology studies (Allan and Daniels 1982). According to our observations, the examined essential oils need to be cautiously applied as alternatives to conventional insecticides and may be used in combination with biological control agents within an IPM program. We suggest that shelf life of essential oils and side-effects on natural enemies should be further evaluated under semi-field and field conditions before they can be included as part of holistic approach in pest-control programs.

\section{Declarations}

\section{Conflicts of Interest}

The authors declare that they have no competing interests. The authors did not receive funds for the submitted work.

\section{Author contribution}

SG and $Y Z$ conceived and designed the experimental plan. SG and $Y Z$ are considered joint corresponding authors. SG performed the experiments and wrote first draft of manuscript. GM, GA assisted with data analysis. All authors commented on manuscript. All authors approved the final manuscript.

\section{Acknowledgements}

The authors would like to appreciate the University of Guilan and Urmia University, Iran for the provided support.

\section{Ethical approval}

This study does not contain any experiments using any animal species that require ethical approval.

\section{References}


1. Ali A, Tabanca N, Demirci B, Blythe EK, Can Baser KH, Khan IA (2016) Chemical composition and biological activity of essential oils from four Nepeta species and hybrids against Aedes aegypti (L.) (Diptera: Culicidae). Rec Nat Prod 10:137-147

2. Alinejad M, Kheradmand K, Fathipour $Y$ (2014) Sublethal effects of fenazaquin on life table parameters of the predatory mite Amblyseius swirskii (Acari: Phytoseiidae). Exp Appl Acarol 64: 361-373

3. Allan JD, Daniels RE (1982) Life table evaluation of chronic exposure of Eurytemora affinis (Copepoda) to kepone. Mar Biol 66:179-184

4. Amizadeh M, Hejazi MJ, Askari Saryazdi G (2013) Fumigant toxicity of some essential oils on Tetranychus urticae (Acari: Tetranychidae). Int J Acarol 39:285-289

5. Aslan I, Özbek H, Çalmaşur Ö, Şahin F (2004) Toxicity of essential oil vapours to two greenhouse pests, Tetranychus urticae Koch and Bemesia tabaci Genn. Ind Crops Prod 19:167-173

6. Atanasova D, Leather SR (2018) Plant essential oils: the way forward for aphid control? Ann Appl Biol. https://doi.org/10.1111/aab.12451

7. Attia S, Grissa KL, Lognay G, Bitume E, Hance T, Mailleux AC (2013) A review of the major biological approaches to control the worldwide pest Tetranychus urticae (Acari: Tetranychidae) with special reference to natural pesticides. J Pest Sci 86:361-386

8. Baker RF, Mohammed MI, El-Gammal EM, Mahdy NM (2009) Biological effects of chitin synthesis inhibitors, hexaflumuron compound on the desert locust, Schistocerca gregaria (Forskal). Egypt Acad J Biol Sci 1:49-57

9. Bashari E, Ghadamyari M, Jalali Sendi J (2014) Toxicity, and biological and biochemical effects of hexaflumuron on the elm leaf beetle, Xanthogaleruca Iuteola (Col.: Chrysomelidae). J Entomol Soc Iran 34:35-46

10. Birkett Michael A, Toby JA, John A (2010) Repellent activity of Nepeta grandiflora and Nepeta clarkei (Lamiaceae) against the cereal aphid, Sitobion avenae (Homoptera: Aphididae). Phytochem Lett 3:139142

11. Bizhannia AR, Etebari K Sorati R (2005) The effects of juvenile hormone analogue, Admiral, application on protein metabolism of silkworm larvae. J Entomol Soc Iran 25:43-56

12. Bradford MM (1976) A rapid and sensitive method for the quantitation of microgram quantities of protein utilizing the principle of protein dye binding. Anal Biochem 72:248-254

13. Çalmaşur Ö, Aslan İ, Şahin F (2006) Insecticidal and acaricidal effect of three Lamiaceae plant essential oils against Tetranychus urticae Koch and Bemisia tabaci Genn. Industrial Crops and Products 23:140-146

14. Calvo FJ, Knapp M, van Houten YM, Hoogerbrugge H, Belda JE (2015) Amblyseius swirskii: What made this predatory mite such a successful biocontrol agent? Exp Appl Acarol 65:419-433

15. Camilo C, Alves Nonato CDF, Galvao-Rodrigues FF, Costa WD, Clemente GG, Macedo S et al (2017) Acaricidal activity of essential oils: a review. Trend Phytochem Res 1:183-198

16. Campolo O, Puglisi I, Barbagallo RN, Cherif A, Ricupero M, Biondi A at al (2020) Side effects of two citrus essential oil formulations on a generalist insect predator, plant and soil enzymatic activities.

Chemosphere. https://doi.org/10.1016/j.chemosphere.2020.127252 
17. Carreño OAL, Palacio-Cortés AM, Navarro-Silva MA, Kouznetsov VV, Duque LJE (2018) Behavior of detoxifying enzymes of Aedes aegypti exposed to girgensohnine alkaloid analog and Cymbopogon flexuosus essential oil. Comp Biochem Physiol C Toxicol Pharmacol 204:14-25

18. Chapman RF (1998) The Insect structre and function, 4th edition, Cambridga Uniuersity Press, Cambridge

19. Chi H, Liu H (1985) Two new methods for the study of insect population ecology. Bull Inst Zool Acad Sin $24: 225-240$

20. Chi H (1988) Life table analysis incorporating both sex and variable development rate among individuals. Environ Entomol 17:26-34

21. Chi H, Su HY (2006) Age-stage, two-sex life tables of Aphidius gifuensis (Ashmead) (Hymenoptera: Braconidae) and its host Myzus persicae (Sulzer) (Homoptera: Aphididae) with mathematical proof of the relationship between female fecundity and the net reproductive rate. Environ Entomol 35:10-21

22. Chi H (2017) TWOSEX-MSChart: a computer program for the age-stage, two-sex life table analysis. http://140.120.197.173/Ecology/

23. Dauterman WC (1985) Insect metabolism: extramicrosomal, ed. by Kerkut GA and Gilbert LI. Comprehensive insect physiology, biochemistry and pharmacology. Pergamon: Oxford, pp 713-730

24. De Araújo MJC, da Câmara CAG, Born FS, de Moraes MM (2020) Acaricidal activity of binary blends of essential oils and selected constituents against Tetranychus urticae in laboratory/greenhouse experiments and the impact on Neoseiulus californicus. Exp Appl Acarol 80:423-444

25. Desneux N, Decourtye A, Delpuech JM (2007) The sublethal effects of pesticides on beneficial arthropods. Annu Rev Entomol 52:81-106

26. Doğramaci M, Kakkar G, Kumar V, Chen J, Arthurs S (2013) Swirski Mite Amblyseius swirskii AthiasHenriot (Arachnida: Mesostigmata: Phytoseiidae). EENY 565, UF/IFAS Exten.

https://edis.ifas.ufl.edu/in1001

27. Ebadollahi A, Sendi JJ, Aliakbar A, Razmjou J (2015) Acaricidal activities of essential oils from Satureja hortensis (L.) and Teucrium polium (L.) against the two spotted spider mite, Tetranychus urticae Koch (Acari: Tetranychidae). Egypt J Biol Pest Control 25:171-176

28. Efron B, Tibshirani RJ (1993) An introduction to the bootstrap. Chapman and Hall, New York

29. Esmaeily M, Bandani AR, Zibaee I, Sharifian I, Zare Sh (2017) Sublethal effects of Artemisia annua L. and Rosmarinus officinalis L. essential oils on life table parameters of Tetranychus urticae (Acari:

Tetranychidae). Persian J Acarol 6:39-52

30. Etebari K, Bizhannia AR, Sorati R, Matindoost L (2007) Biochemical changes in haemolymph of silkworm larvae due to pyriproxyfen residue. Pestic Biochem Physiol 88:14-19

31. Farahani S, Bandani AR, Azam Amiri (2020) Toxicity and repellency effects of three essential oils on two populations of Tetranychus urticae (Acari: Tetranychidae). Persian J Acarol 9:67-81

32. Fatemikia S, Abbasipour $H$, Saeedizadeh A (2017) Phytochemical and acaricidal study of the galbanum, Ferula gumosa Boiss. (Apiaceae) essential oil against Tetranychus urticae Koch (Tetranychidae). J Essent Oil Bear Plant 20:185-195

33. Fernandes FL, Bacci L, Fernandes MS (2010) Impact and Selectivity of Insecticides to Predators and Parasitoids. Entomo Brasilis 3:01-10 
34. Freitas GSD, Santos MCD, Lira VDA, Galvão AS, Oliveira EE, Filho JGDS et al (2018) Acute and non-lethal effects of coconut oil on predatory mite Typhlodromus ornatus (Acari: Phytoseiidae). Syst Appl Acarol 23:1333-1341

35. Gao Q, Song L, Sun J, Cao HQ, Wang L, Lin H et al (2019) Repellent action and contact toxicity mechanisms of the essential oil extracted from Chinese chives against Plutella xylostella larvae. Arch Insect Biochem Physiol. https://doi.org/10.1002/arch.21509

36. Gaspari M, Lykouressis D, Perdikis D, Polissiou D (2007) Nettle extract effects on the aphid Myzus persicae and its natural enemy, the predator Macrolophus pygmaeus (Hem: Miridae). J Appl Entomol 131:652-657

37. Geiger F, Bengtsson J, Berendse F, Weisser WW, Emmerson M, Morales MB et al (2010) Persistent negative effects of pesticides on biodiversity and biological control potential on European farmland. Basic Appl Ecol 11:97-105

38. Ghasemzadeh S, Leman A, Messelink GJ (2017) Biological control of Echinothrips americanus by phytoseiid predatory mites and the effect of pollen as supplemental food. Exp Appl Acarol. https://doi.org/10.1007/s10493-017-0191-1

39. Ghasemzadeh S, Qureshi JA (2018) Demographic analysis of fenpyroximate and thiacloprid exposed predatory mite Amblyseius swirskii (Acari: Phytoseiidae). PLOS ONE.

https://doi.org/10.1371/journal.pone.0206030

40. Gholamzadeh-Chitgar M, Hajizadeh J, Ghadamyari M, Karimi-Malati A, Hoda H (2015) Effects of sublethal concentration of diazinon, fenitrothion and chlorpyrifos on demographic and some biochemical parameters of predatory bug, Andrallus spinidens Fabricius (Hemiptera: Pentatomidae) in laboratory conditions. Int J Pest Manage. http://dx.doi.org/10.1080/09670874.2015.1035772

41. Gigon V, Camps C, Le Corff J (2016) Biological control of Tetranychus urticae by Phytoseiulus macropilis and Macrolophus pygmaeus in tomato greenhouses. Exp Appl Acarol 68:55-70

42. Habig WH, Pabst MJ, Jakoby WB (1974) Glutathion s-transferase, the first step in mercapturic acid formation. J Biol Chem 249:7130-7139

43. Havasi MR, Kheradmand K, Mosallanejad H, Fathipour Y (2019) Sublethal effects of diflovidazin on demographic parameters of the predatory mite, Neoseiulus californicus (Acari: Phytoseiidae) Int J Acarol. https://doi.org/10.1080/01647954.2019.1607550

44. Havasi M, Kheradmand K, Mosallanejad H, Fathipour Y (2020) Life history traits and demographic parameters of Neoseiulus californicus McGregor (Acari: Phytoseiidae) treated with the Biomite ${ }^{\circledR}$. Sys Appl Acarol 25:125-138

45. Hayaoka T, Dauterman WC (1982) Induction of glutathione stransferase by phenobarbital and pesticide in various housefly strains and its effects in toxicity. Pestic Biochem Physiol 17:113-119

46. Hayes JD, Pulford DI (1995) The glutathioue S-transferase supergene family regulation of GST and the contribution of the isoenzymes to cancer chemoprotection and drug resistance. Crit Rev Biochem Mol Biol 30:445-600

47. Heidary M, Jafari Sh, Karimzadeh J, Negahban M, Shakarami J (2020) The effects of pure and nanocapsulated formulations of Thymus daenensis Celak. (Lamiaceae) essential oil on life-table parameters of cabbage aphid (Brevicoryne brassicae L.) (Hem.: Aphididae). Plant Pest Res 10:15-32 
48. Hodge S, Longley M, Booth L, Heppelthwaite V, O'Halloran K (2000) An evaluation of glutathione Stransferase activity in the Tasmanian lacewing (Micromus tasmaniae) as a biomarker of organophosphate contamination. Bull Environ Contam Toxicol 65:8-15

49. Hyne RV, Maher WA (2003) Invertebrate biomarkers: links to toxicosis that predict population decline. Ecotoxicol Environ Saf 54:366-374

50. Isman MB, Grieneisen ML (2014) Botanical insecticide research: many publications, limited useful data. Trends Plant Sci 19:140-145

51. Janssen A, van Rijn PCJ (2021) Pesticides do not significantly reduce arthropod pest densities in the presence of natural enemies. Ecol Lett. https://doi.org/10.1111/ele.13819

52. Jeppson LR, Keifer HH, Baker EW (1975) Mites Injurious to Economic Plants. University of California Press, Berkeley

53. Lamoureux GL, Rusness DG (1987) Synergism of diazinon toxicity and inhibition of diazinon metabolism in the house fly by Tridiphane: inhibition of glutathione-Stransferase activity. Pestic Biochem Physiol 27:318-329

54. Liao M, Xiao JJ, Zhou LJ, Yao X, Tang F, Hua M et al (2017) Chemical composition, insecticidal and biochemical effects of Melaleuca alernifolia essential oil on the Helicoverpa armigera. J Appl Entomol 141:721-728

55. Lima DB, Melo JWS, Guedes NMP, Gontijo LM, Guedes RNC, Gondim Jr MGC (2015) Bioinsecticidepredator interactions: azadirachtin behavioral and reproductive impairment of the coconut mite predator Neoseiulus baraki. PLOS ONE. https://doi.org/10.1371/journal.pone.0118343

56. Lira ACS, Zanardi OZ, Beloti VH, Bordini GP, Yamamoto PT, Parra JRP et al (2015) Lethal and Sublethal Impacts of Acaricides on Tamarixia radiata (Hemiptera: Eulophidae), an important Ectoparasitoid of Diaphorina citri (Hemiptera: Liviidae). J Econ Entomol. https://doi.org/10.1093/jee/tov189

57. Mamduh Z, Hosseininaveh V, Allahyari H, Talebi-Jahromi Kh (2017) Side effects of garlic extract on the life history parameters of the predatory bug, Podisus maculiventris (Say) (Hemiptera: Pentatomidae). Crop Prot 100:65-72

58. Mar JM, Silva LS, Azevedo SG, França LP, Goes AFF, Santos AL et al (2018) Lippia origanoides essential oil: an efficient alternative to control Aedes aegypti, Tetranychus urticae and Cerataphis lataniae. Ind Crop Prod 111:292-297

59. Mathieu C, Duval R, Xu X, Rodrigues-Lima F, Dupret JM (2015) Effects of pesticide chemicals on the activity of metabolic enzymes: focus on thiocarbamates. Expert Opin Drug Metab Toxicol 11:81-94

60. Messelink GJ, Van Maanen R, Van Steenpaal SEF, Janssen A (2008) Biological control of thrips and whiteflies by a shared predator: Two pests are better than one. Biol Control 44:372-379

61. Messelink GJ, Van Maanen R, Van Holstein-Saj R, Sabelis MW, Janssen A (2010) Pest species diversity enhances control of spider mites and whiteflies by a generalist phytoseiid predator. BioControl 55:387-398

62. Miresmailli S, Bradbury R, Isman MB (2006) Comparative toxicity of Rosmarinus officinalis L. essential oil and blends of its major constituents against Tetranychus urticae Koch (Acari: Tetranychidae) on two different host plants. Pest Manag Sci 62:366-371 
63. Momen FM, Amer SAA, Refaat AM (2001) Influence of mint and peppermint on Tetranychus urticae and some predacious mites of the family phytoseiidae (Acari: Tetranychidae: Phytoseiidae). Acta Phytopathol Entomol Hung 36:143-153

64. Momen FM, Amer SA (2003) Influence of the sweet basil, Ocimum basilicum L. on some predacious mites of the family Phytoseiidae (Acari: Phytoseiidae). Acta Phytopathol Entomol Hung 38:137-143

65. Monteiro VB, Gondim JMGC, Oliveira JEM, Siqueira HAA, Sousa JM (2015) Monitoring Tetranychus urticae Koch (Acari: Tetranychidae) resistance to abamectin in vineyards in the Lower Middle São Francisco Valley. Crop Prot 69:90-96

66. Moscardini VF, da Costa Gontijo P, Carvalho GA, de Oliveira RL, Maia JB, Silva FF (2013) Toxicity and sublethal effects of seven insecticides to eggs of the flower bug Orius insidiosus (Say) (Hemiptera: anthocoridae). Chemosphere 92:490-496

67. Motoyama N (1980) Glutathione-S-transferases: their role in the metabolism of organophosphorus insecticides. Rev Biochem Toxicol 2:49-69

68. Mouches C, Pasteur N, Berge JB, Hyrien O, Raymound M, De Saint Vincent BR et al (1986) Amplification of an esterase gene is responsible for insecticide resistance in a Californian Culex mosquito. Science 233:778-780

69. Nadimi A, Kamali K, Arbabi M, Abdoli F (2011) Study on persistence tests of miticides abamectin and fenpyroximate to the predatory mite Phytoseiulus persimilis (Acarina: Phytoseiidae). Afr J Agric Res 6:338342

70. Nathan SS, Choi MY, Seo HY, Paik CH, Kalaivani K, Kim JD (2008) Effect of azadirachtin on acetylcholine esterase activity and histology of brown plant hopper Nilaparvata lugens (Stal). Ecotox Environ Safety 70:244-250

71. Obeng-Ofori D, Reichmuth C, Bekele J, Hassanali A (1997) Biological activity of 1,8-cineole, a major component of essential oil of Ocimum kenyense (Ayobangira) against stored products beetles. J Appl Entomol 121:237-243

72. Oliveira NNFC, Galvão AS, Amaral EA, Santos AWO, Sena-Filho JG, Oliveira EE et al (2017) Toxicity of vegetable oils to the coconut mite Aceria guerreronis and selectivity against the predator Neoseiulus baraki. Exp Appl Acarol 72:23-34

73. Opit GP, Nechols JR, Margolies DC (2004) Biological control of two spotted spider mites, Tetranychus urticae Koch (Acari: Tetranychidae), using Phytoseiulus persimilis Athias-Henriot (Acari: Phytoseidae) on ivy geranium: assessment of predator release ratios. Biol Control 29: 445-452

74. Pavela R (2015) Essential oils for the development of eco-friendly mosquito larvicides: A review. Ind Crops Prod 76:174-187

75. Pizzorno JND (2014) Glutathione. Integrative Med Clin J 13:8-12

76. Poderoso JCM, Correia-Oliveira ME, Chagas ThX, Zanuncio JC, Ribeiro GT (2016) Effects of plant extracts on developmental stages of the predator Podisus nigrispinus (Hemiptera: Pentatomidae). Fla Entomol. https://doi.org/10.1653/024.099.0121

77. Poorjavad N, Goldansaz SH, Dadpour H, khajehali J (2014) Effect of Ferula assafoetida essential oil on some biological and behavioral traits of Trichogramma embryophagum and T. evanescens. BioControl 59:403-413 
78. Reddy GVP, Chi H (2015) Demographic comparison of sweetpotato weevil reared on a major host, Ipomoea batatas, and an alternative host, I triloba. Sci Rep. https://doi.org/10.1038/srep11871

79. Regnault-Roger C, Vincent C, Arnason JT (2012) Essential oils in insect control: low-risk products in a highstakes world. Annu Rev Entomol 57:405-424

80. Remia B, Logaswamy MS, Lognkumay K, Rajmohan D (2008) Effect of an insecticide (monocrotophos) on some biochemical constituents of the fish, Tilapia mossambica. Pollut Res 27:523-526

81. Rezaei R, Karimi J, Abbasipour H, Askarianzadeh AR (2014) Sublethal effects of essential oil of Cinnamomum zeylanicum Blume on life expectancy $\left(e_{x}\right)$ and age-specific fertility $\left(m_{x}\right)$ of two-spotted spider mite, Tetranychus urticae Koch (Acari: Tetranychidae). Arch Phytopathol Plant Protect 47:900-905

82. Ribeiro N, da Camara CAG, Ramos C (2016) Toxicity of essential oils of Piper marginatum Jacq. against Tetranychus urticae Koch and Neoseiulus californicus (McGregor). Chilean J Agric Res. http://dx.doi.org/10.4067/S0718-58392016000100010

83. Ross MK, Streit TM, Herring KL (2010) Carboxylesterases: Dual roles in lipid and pesticide metabolism. J Pestic Sci 35:257-264

84. Roush RT (1989) Designing resistance management programs: how can you choose? Pestic Sci 26:423441

85. Rufingier C, Pasteur N, Lagnel J, Martin C, Navajas M (1999) Mechanisms of insect resistance in the aphid, Nasonovia ribisnigri (Mosley) (Homoptera: Aphididae), from France. Insect Biochem Mol Biol 29:385-91

86. Sak O, Uçkan F, Ergin E (2006) Effects of cypermethrin on total body weight, glycogen, protein, and lipid contents of Pimpla turionellae(L.) (Hymenoptera: Ichneumonidae). Belg J Zool 136:53-58

87. Salman SY, Bayram E (2017) Contact toxicities of some plant extracts in Apiaceae family on different developmental stages of Tetranychus urticae Koch, 1836 (Acari: Tetranychidae). Türk entomol derg 41:243-250

88. Saraiva WVA, Vieira IG, Galvão AS, do Amaral EA, Rêgo AS, Teodoro AV et al (2020) Lethal and sublethal effects of babassu and degummed soybean oils on the predatory mite Typhlodromus ornatus (Acari: Phytoseiidae). Int J Acarol. https://doi.org/10.1080/01647954.2020.1734081

89. Sarbaz S, Goldasteh Sh, Zamani AA, Solymannejadiyan E, Vafaei Shoushtari R (2017) Side effects of spiromesifen and spirodiclofen on life table parameters of the predatory mite, Neoseiulus californicus McGregor (Acari: Phytoseiidae). Int J Acarol. DOI: 10.1080/01647954.2017.1325396

90. Shahbaz M, Khoobdel M, Khanjani M, Hosseininia A, Javadi Khederi S (2019) Sublethal effects of acetamiprid on biological aspects and life table of Amblyseius swirskii (Acari: Phytoseiidae) fed on Aleuroclava jasmini (Hemiptera: Aleyrodidae). Syst Appl Acarol 24:814-824

91. Shojaei A, Talebi Kh, Sharifian I, Ahsaei SM (2017) Evaluation of detoxifying enzymes of Tribolium castaneum and Tribolium confusum (Col.: Tenebrionidae) exposed to essential oil of Artemisia dracunculus L. Biharean Biologist 11:5-9

92. SPSS (2012) IBM SPSS Statistics for Windows, Version 21.0. Armonk, NY: IBM Corp

93. Sugumaran M (2010) Chemistry of cuticular sclerotization. J Adv Insect Physiol 39:151-209 
94. Tavares WS, Costa MA, Cruz I, Silveira RD, Serrão JE, Zanuncio JC (2010) Selective effects of natural and synthetic insecticides on mortality of Spodoptera frugiperda (Lepidoptera: Noctuidae) and its predator Eriopis connexa (Coleoptera: Coccinellidae). J Environ Sci Health B 45:557-561

95. Tedeschi R, Alma A, Tavella L (2001) Side-effects of three neem (Azadirachta indica A. Juss) products on the predator Macrolophus caliginosus Wagner (Het., Miridae). J Appl Entomol 125:397-402

96. Usui K, Fukami J, Shishido T (1977) Insect glutathione S-transferase separation of transferases from fat bodies of american cockroaches active on organophosphorus trimesters. Pestic Biochem Physiol 7:249260

97. Van Asperen K (1962) Study of housefly esterases by mean of sensitive colorimetric method. J Insect Physiol 8:401-416

98. Van de Vrie M, McMurtry JA, Huffaker CB (1972) Ecology of tetranychid mites and their natural enemies: a review. III. Biology, ecology, and pest status, and host- plant relations of tetranychids. Hilgardia 41:343-432

99. Yang RSH (1976) Enzyme conjugation and insecticide metabolism, ed. by Wilkinson CF, Biochemistry and physiology of insecticides. New York (NY): Plenum Press, pp 177-187

100. Yorulmaz Salman S, Ay R (2013) Analysis of hexythiazox resistance mechanisms in a laboratory selected predatory mite Neoseiulus californicus (Acari: Phytoseiidae). Türk Entomol Derg 37:409-422

101. Yorulmaz-Salman S, Ay R (2014) Determination of the inheritance, cross-resistance and detoxifying enzyme levels of a laboratory-selected, spiromesifen-resistant population of the predatory mite Neoseiulus californicus (Acari: Phytoseiidae). Pest Manag Sci 70:819-826

102. Yuval B, Kaspi R, Shloush S, Warburg MS (1998) Nutritional reserves regulate male participation in Mediterranean fruit fly leks. Ecol Entomol 23:211-215

103. Zanuncio JC, Mourão SA, Martínez LC, Wilcken CF, Ramalho FS, Plata-Rueda A et al (2016) Toxic effects of the neem oil (Azadirachta indica) formulation on the stink bug predator, Podisus nigrispinus (Heteroptera: Pentatomidae). Sci Rep. https://doi.org/10.1038/srep30261

104. Zekri N, Amalich S, Boughdad A, Alaoui E, Belghiti M, Zair T (2013) Phytochemical study and insecticidal activity of Mentha pulegium L. oils from Morocco against Sitophilus Oryzae. Mediterr J Chem 2:607-619

\section{Figures}



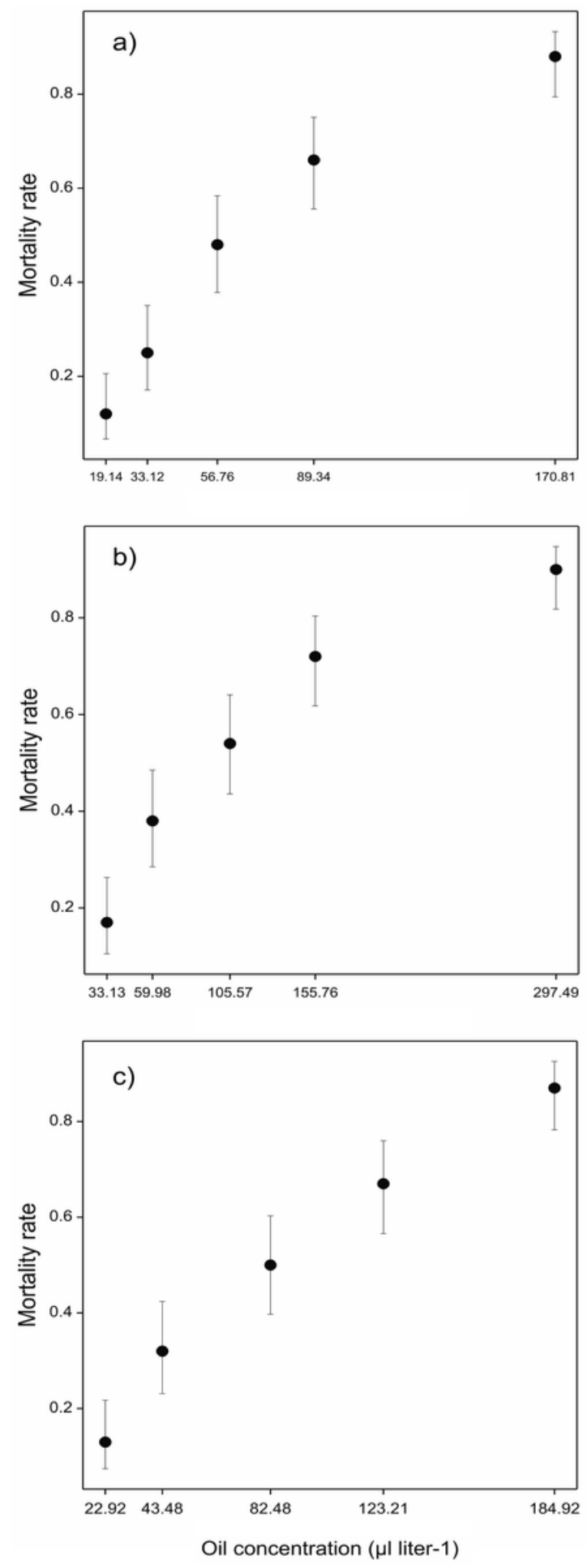

Figure 1

Estimated mean mortality of T. urticae adults by residual concentrations of a) N. crispa, b) S. hortensis, and c) A. graveolens. The circles are the back-transformed predicted means by the GLM model and the vertical lines show back-transformed $95 \%$ confidence intervals. Non-overlaping confidence intervals within each oil concentration suggest evidence of statistically significant difference 


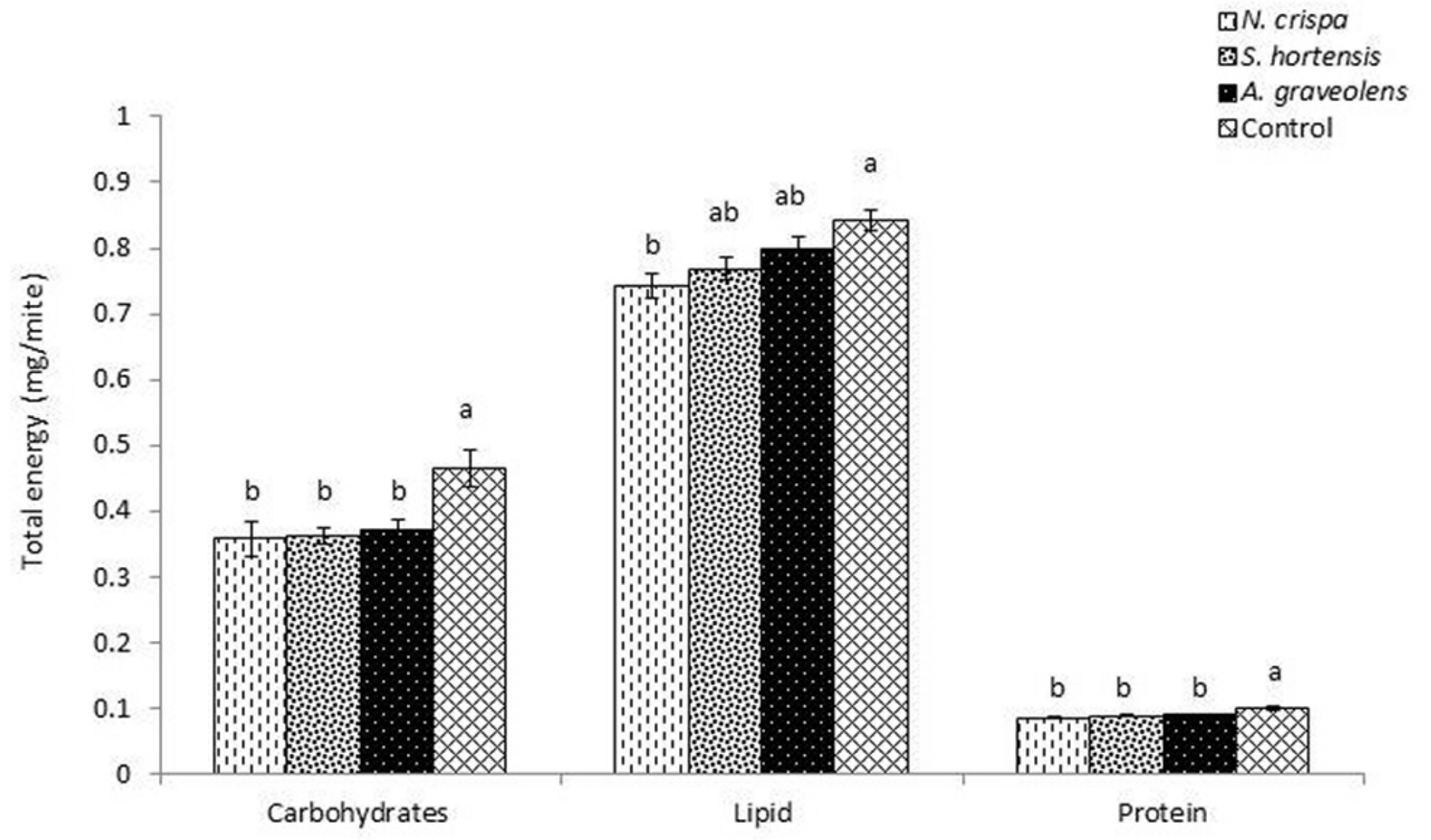

\section{Figure 2}

Total energy content (mean \pm SE) of the carbohydrate, lipid and protein reserves of A. swirskii females exposed to N. crispa, S. hortensis and A. graveolens. Different letters indicate significant differences based on Tukey's test $(P=0.05)$ 
[N N. crispa

QS. hortensis

-A. graveolens

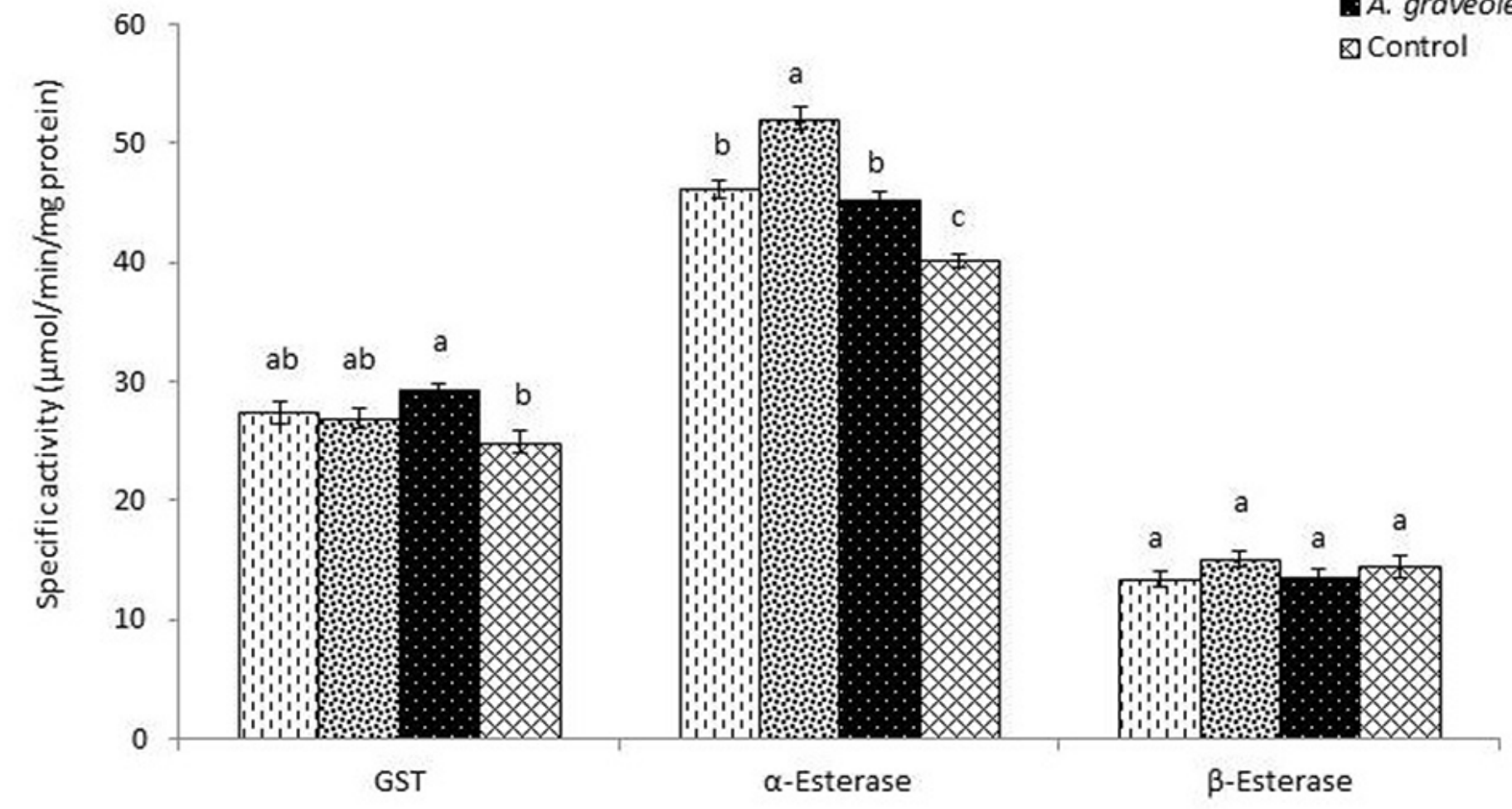

aControl

\section{Figure 3}

The enzymes activity (mean \pm SE) of A. swirskii ( $\mu$ mol min-1 mg protein-1) females exposed to N. crispa, S. hortensis and A. graveolens. Different letters indicate significant differences based on Tukey's test $(P=0.05)$ 

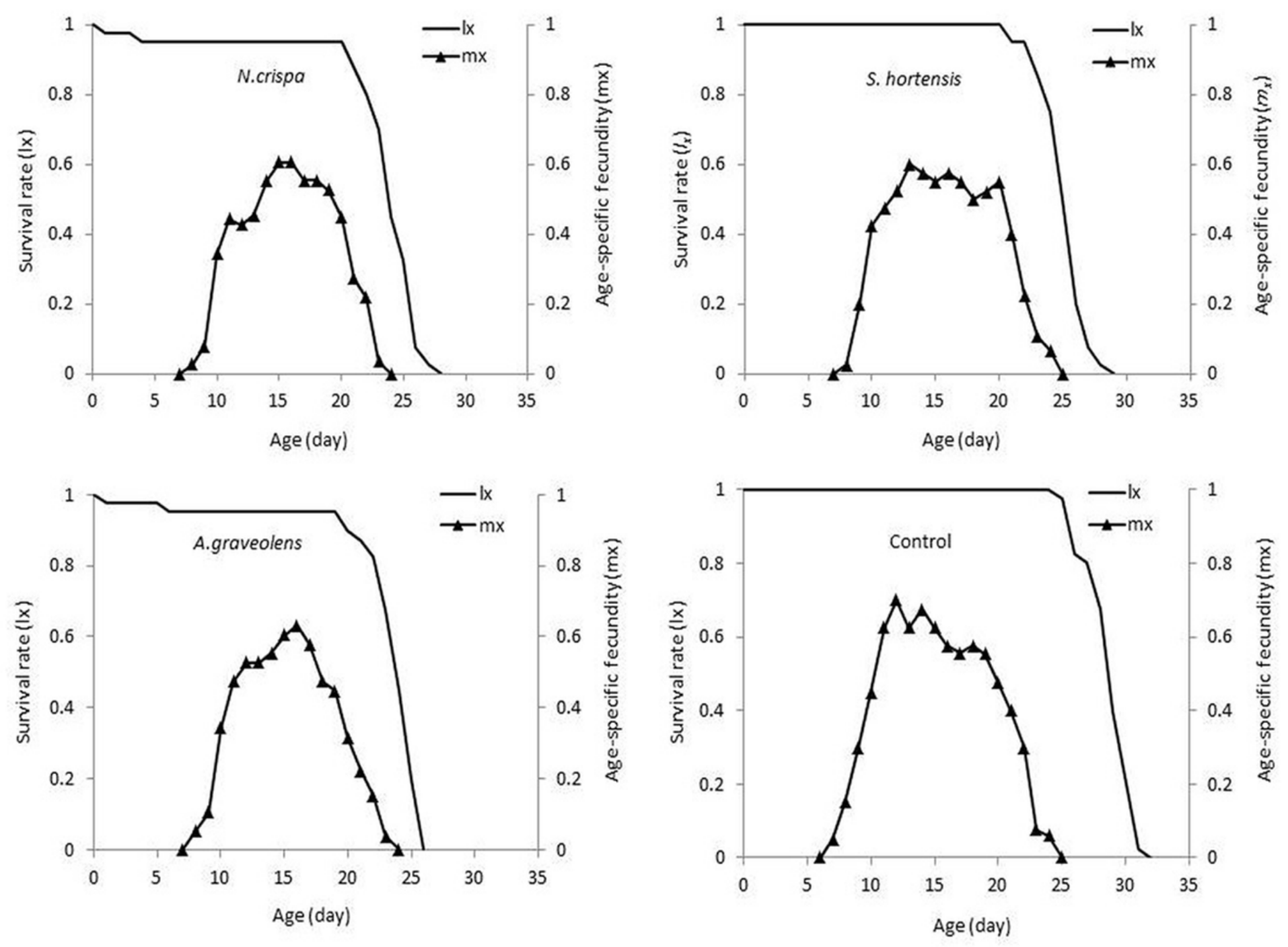

Figure 4

Age-specific survival (Ix) and age-specific fecundity $(\mathrm{mx})$ of the population of A. swirskii females from control or treatments of N. crispa, S. hortensis and A. graveolens 

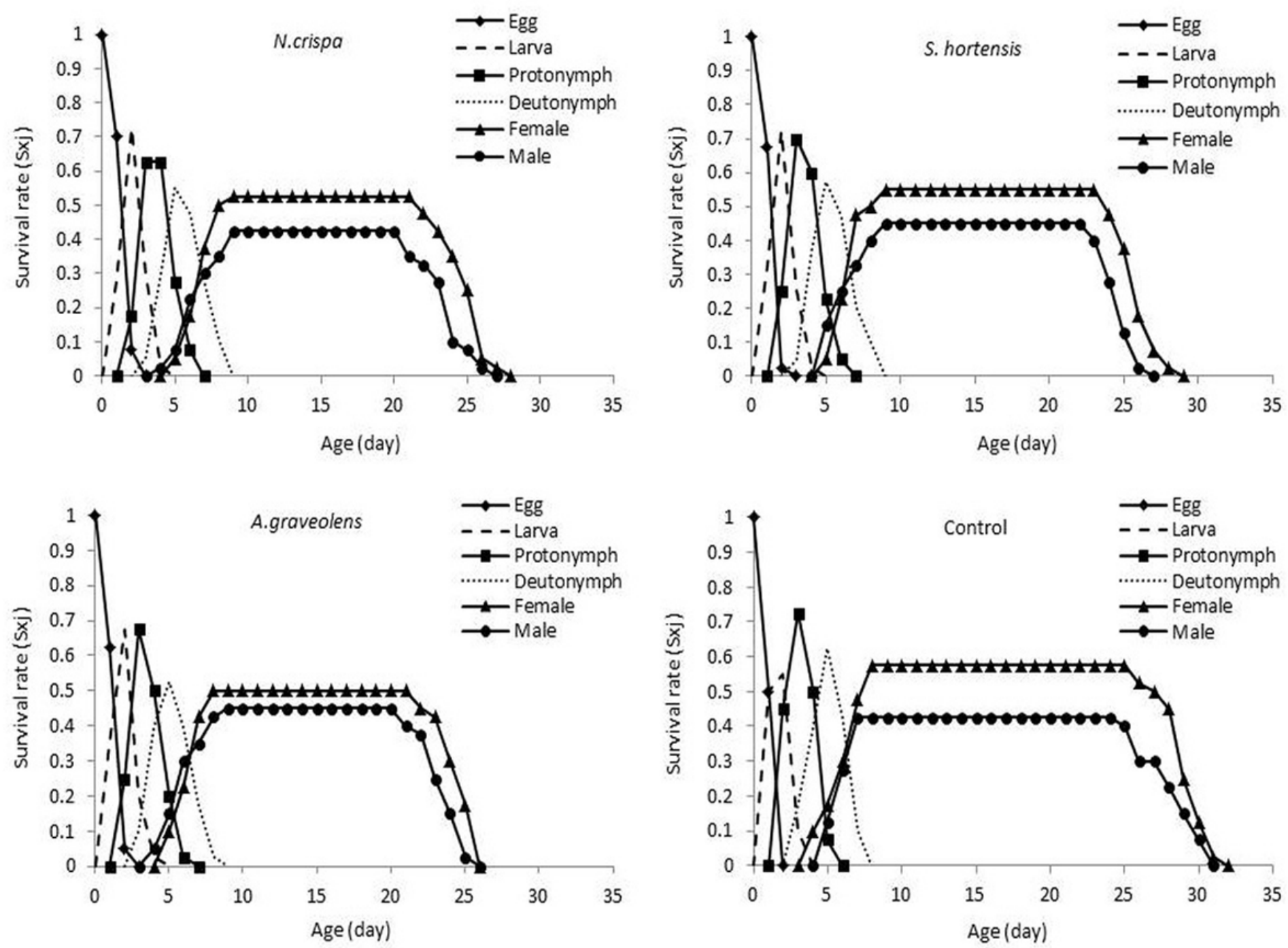

Figure 5

Age-stage specific survival rate (sxj) of the population from A. swirskii females from control or treatments of $\mathrm{N}$. crispa, S. hortensis and A. graveolens 

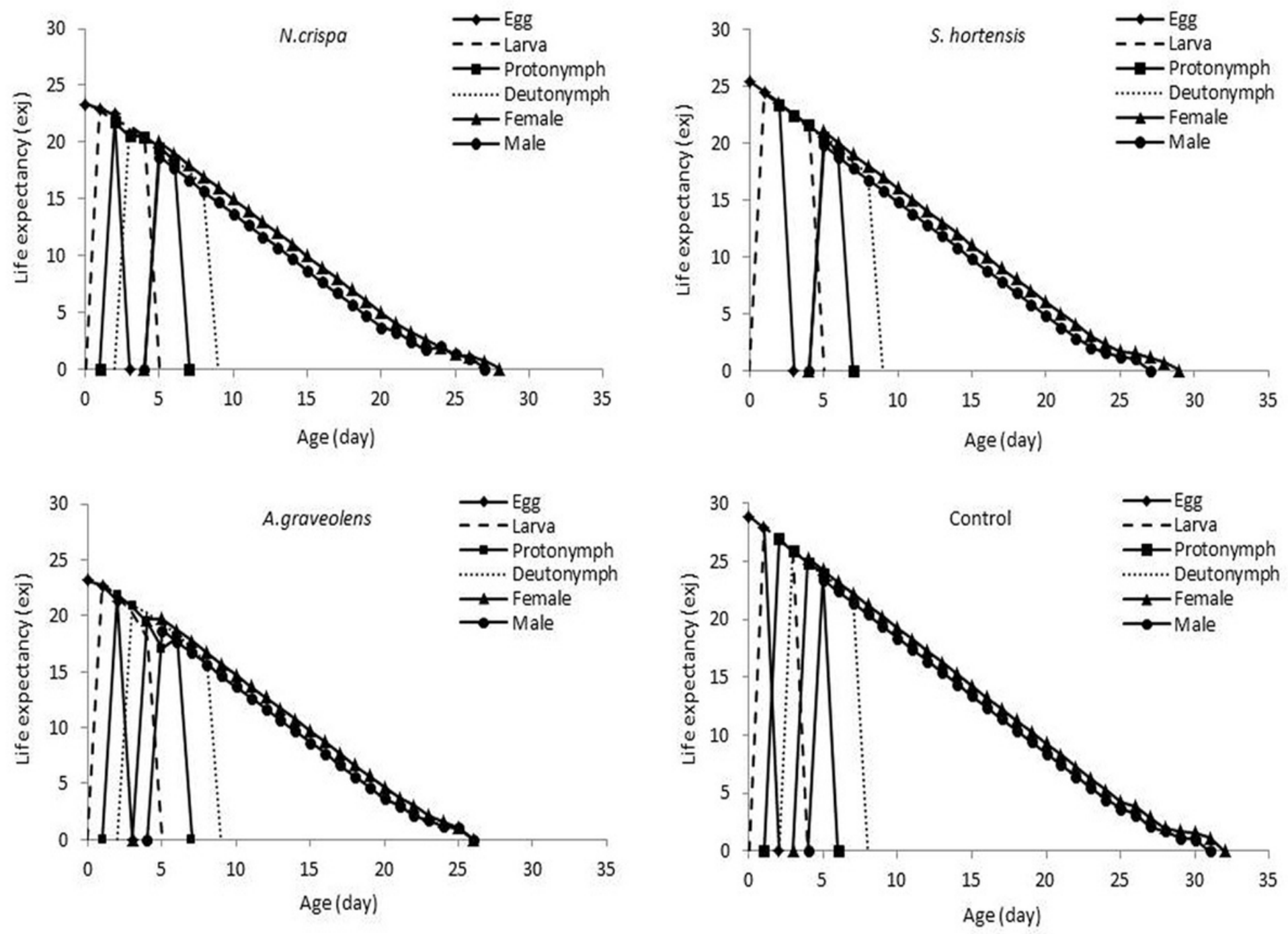

Figure 6

Age-stage life expectancy (exj) of A. swirskii females from control or treatments of N. crispa, S. hortensis and A. graveolens 